\title{
Importance of halide involving interactions at Hoogsteen sites in supramolecular architectures of some coordination metal complexes of $\mathrm{N}^{6}$-benzyl/furfuryl adenine
}

\author{
Samson Jegan Jennifer, Packianathan Thomas Muthiah ${ }^{*}$ and Duraiswamy Tamilselvi
}

\begin{abstract}
Background: Most of the benzyladenine and furfuryladenine derivatives inhibit tumor/cancer cell growth; their toxicity is lesser than the compounds used for the treatment of cancer now-a-days. Many cytokinin derivatives are tested for anticancer activity.

Results: A series of transition metal complexes containing $\mathrm{N}^{6}$-benzyl/furfuryl aminopurines of formula $\left[\mathrm{Mn}(\mathrm{FAH})_{2}\right.$ $\left.\left(\mathrm{H}_{2} \mathrm{O}\right)\left(\mathrm{Cl}_{3}\right)\right]_{2} \cdot \mathrm{Cl}_{2}(1),\left[\mathrm{Co}(\mathrm{FAH}) 2\left(\mathrm{H}_{2} \mathrm{O}\right)\left(\mathrm{Cl}_{3}\right)\right]_{2} \cdot \mathrm{Cl} 2(2),\left[\mathrm{Co}(\mathrm{FAH})_{2}\left(\mathrm{Cl}_{4}\right)\right]_{2}$. $\left.\mathrm{CO}(\mathrm{FAH})_{2}\left(\mathrm{H}_{3} \mathrm{O}\right)\left(\mathrm{Cl}_{3}\right)\right] \cdot \mathrm{Cl}{ }_{2}(3),\left[\mathrm{Ni}(\mathrm{FAH})_{2}\left(\mathrm{H}_{2} \mathrm{O}\right)\left(\mathrm{Cl}_{3}\right)\right]_{2} \cdot \mathrm{Cl}_{2}$ $(\mathrm{H} 2 \mathrm{O})(4),\left[\mathrm{Zn}(\mathrm{BAH}) \mathrm{Br}_{3}\right](5)$ and $\left[\mathrm{Cd}_{2}(\mathrm{BAH})_{2}\left(\mu-\mathrm{Br}_{4} \mathrm{Br}_{2}\right]_{n}\right.$ (6) (where $\mathrm{BAH}$ and $\mathrm{FAH}$ benzyladeninium and furfuryladeninium cations respectively) have been synthesized and characterized. Crystal structures of (1-4) have similar distorted octahedral coordination geometry, while (5) and (6) have distorted tetrahedral geometry and octahedral geometries respectively. In (1-4) two halide ions and two cytokinin cations $\left(\mathrm{BAH}^{+} / \mathrm{FAH}^{+}\right)$are laterally coordinated to the metal ion. A water molecule and a halide ion are axially coordinated. But the coordination sphere of (5) consists of N7 coordinated benzyladeninium ion and three halide ions. The complex (6) is a coordination polymer bridged by bromide anions. A common notable feature in (1-4) is the presence of one or more lattice chloride anions. They help in a chain formation by $\mathrm{N}-\mathrm{H} \ldots \mathrm{Cl}$ halide involving hydrogen bonding interactions in between the Hoogsteen site hydrogen.
\end{abstract}

Conclusions: The observed crystal structures emphasize the role of the halide ions in developing the supramolecular architectures by halide involving hydrogen bonding interactions. Also most of the reported cobalt cytokinin complexes possess tetrahedral coordination geometry, but some cobalt complexes have distorted octahedral coordination geometry, which are discussed and compared.

Keywords: $\mathrm{N}^{6}$-benzyladenine, $\mathrm{N}^{6}$-furfuryladenine, X-ray diffraction studies, Crystal structures, Supramolecular architectures

\section{Background}

Molecular crystal engineering involving an organic ligand coordinated to metal ions which are self assembled in the formation of supramolecular architectures is a field of evergreen interest. This self assembly process is governed by a variety of hydrogen bonding and $\pi-\pi$ stacking interactions. These interactions play a vital role in controlling the properties and in turn the potential applications of the organic-inorganic hybrid materials

* Correspondence: tommtrichy@yahoo.co.in

School of Chemistry, Tiruchirappalli-620024, Tamil Nadu, India
[1]. Their applications involve a wide spectrum ranging from molecular sensing ion-exchange catalysis, magnetism, and gas storage [2-6]. The transition metals such as cobalt, zinc, iron, copper, platinum and palladium enhance the cytotoxic activity of the cytokinins on tumour cells [7-16].

Coordination site of the cytokinins is governed by various factors such as $\mathrm{pH}$, nature of the metal, substituents on the aminopurine skeleton, etc [17-20]. Copper and cadmium cytokinin crystal structures were reported in our laboratory [21-23]. Some of the reported cobalt cytokinin 
complexes have very good anticancer activity (in vitro condition) than the derivatives tested for clinical trials [24].

\section{Experimental section}

Materials and methods

All reagents, solvents and ligands used for syntheses were purchased from commercial sources and used as received.

\section{Preparation of bis[bis(furfuryladeninN1-H ium) manganese} (II) (mono aqua) (trichlorido)] chloride (FAMNCL) (1)

$40 \mathrm{ml}$ aqueous solution of $\mathrm{MnCl}_{2} \cdot 4 \mathrm{H}_{2} \mathrm{O}(0.0495 \mathrm{~g})$ was heated at $95^{\circ} \mathrm{C}$ for $30 \mathrm{~min}$. over a water bath. $0.0717 \mathrm{~g}$ of furfuryladenine and 3 drops of conc. $\mathrm{HCl}$ were added to this solution, and the heating was continued for $90 \mathrm{~min}$. The resultant solution was allowed to slow evaporation at room temperature. After a few days pale green crystals of (1) were obtained.

\section{Preparation of bis[bis(furfuryladeninN1-H ium) cobalt(II)} (mono aqua) (trichlorido)] chloride (FACOCLI) (2)

The preparation procedure of (2) was same as that of (1) except $\mathrm{CoCl}_{2} \cdot 6 \mathrm{H}_{2} \mathrm{O}(0.0595 \mathrm{~g})$ was used instead of $\mathrm{MnCl}_{2} \cdot 4 \mathrm{H}_{2} \mathrm{O}$. After a few days pink prismatic crystal of (2) were obtained.
Preparation of bis[bis(furfuryladeninN1-H ium) cobalt(II) (tetrachlorido)] [bis(furfuryladeninN1-H ium) cobalt(II) (mono aqua) (trichlorido)] chloride (FACOCLII) (3)

$20 \mathrm{ml}$ aqueous solution of $\mathrm{CoCl}_{2} \cdot 6 \mathrm{H}_{2} \mathrm{O}(0.0538 \mathrm{~g})$ was stirred at $40^{\circ} \mathrm{C}$ for $30 \mathrm{~min}$. To this $15 \mathrm{ml}$ ethanolic solution of furfuyladenine $(0.0717 \mathrm{~g})$ and $0.0398 \mathrm{~g}$ of 3 pyridine sulfonic acid were added. It resulted in white turbidity, which was removed by the addition of $5 \mathrm{ml}$ dil. $\mathrm{HCl}$. The solution was further heated at $50^{\circ} \mathrm{C}$ for $90 \mathrm{~min}$. The resultant solution was allowed to slow evaporation at room temperature. After a few days pink coloured precipitate was formed. The pink precipitate was recrystallized using methanol.

Preparation of [bis(furfuryladeninN1-H ium)nickel (II)(mono aqua) (trichlorido)] chloride monohydrate. (FANICL) (4)

The preparation procedure of (4) was same as that of 1 except of $\mathrm{NiCl}_{2} \cdot 6 \mathrm{H}_{2} \mathrm{O}(0.0594 \mathrm{~g})$ was used instead of $\mathrm{MnCl}_{2} \cdot 4 \mathrm{H}_{2} \mathrm{O}$. After a few days green prismatic crystal of (2) were obtained.

\section{Preparation of zinc (II)benzyladeninN1-H ium tri bromido [Zn(BAH+)Br3] BAZNBR (5)}

$40 \mathrm{ml}$ aqueous solution of $\mathrm{ZnBr}_{2}(0.0563 \mathrm{~g})$ was heated at $70^{\circ} \mathrm{C}$ for $30 \mathrm{~min}$. over a magnetic stirrer. $0.0563 \mathrm{~g}$ of

Table 1 Crystal data and structure refinement information for compounds (1-6)

\begin{tabular}{|c|c|c|c|c|c|c|}
\hline & 1 & 2 & 3 & 4 & 5 & 6 \\
\hline Empirical Formula & $\begin{array}{l}\mathrm{C}_{20} \mathrm{H}_{22} \mathrm{Cl}_{3} \mathrm{MnN}_{10} \\
\mathrm{O}_{3}, \mathrm{Cl}\end{array}$ & $\begin{array}{l}\mathrm{C} 20 \mathrm{H} 22 \mathrm{Cl} 3 \mathrm{Co} \\
\mathrm{N} 10 \mathrm{O} 3, \mathrm{Cl}\end{array}$ & $\begin{array}{l}\mathrm{C} 20 \mathrm{H} 23 \mathrm{Cl} 3 \mathrm{Co} N 10 \mathrm{O} 3, \\
\mathrm{C} 20 \mathrm{H} 20 \mathrm{Cl} 4 \mathrm{Co} \mathrm{N} 10 \mathrm{O} 2,2(\mathrm{Cl})\end{array}$ & $\begin{array}{l}\mathrm{C} 20 \mathrm{H} 22 \mathrm{Cl} 3 \mathrm{~N} 10 \mathrm{Ni} \\
\mathrm{O} 3, \mathrm{H} 2 \mathrm{O}, \mathrm{Cl}\end{array}$ & $\begin{array}{l}\mathrm{C} 12 \mathrm{H} 12 \mathrm{Br} 3 \\
\mathrm{~N} 5 \mathrm{Zn}\end{array}$ & $\begin{array}{l}\mathrm{C} 12 \mathrm{H} 12 \mathrm{Br} 3 \\
\mathrm{Cd} \mathrm{N5}\end{array}$ \\
\hline Formula weight & 647.22 & 651.21 & 1320.85 & 668.98 & 531.36 & 578.38 \\
\hline Temp, K & $296(2)$ & $296(2)$ & $296(2)$ & $296(2)$ & $296(2)$ & $296(2)$ \\
\hline$\lambda(\AA)$ & 0.71073 & 0.71073 & 0.71073 & 0.71073 & 0.71073 & 0.71073 \\
\hline Crystal system & Monoclinic & Monoclinic & Triclinic & Orthorhombic & Monoclinic & Tetragonal \\
\hline Space group & $\mathrm{C} 2 / \mathrm{C}$ & $\mathrm{C} 2 / \mathrm{C}$ & $P-1$ & $P 2_{1} 2_{1} 2_{1}$ & $\mathrm{P} 2{ }_{1} / \mathrm{C}$ & P4322 \\
\hline a $(\AA)$ & $22.9002(2)$ & $22.9118(10)$ & $6.9750(1)$ & $12.1423(8)$ & $17.8589(3)$ & $8.2348(3)$ \\
\hline$b(\AA)$ & $16.0257(2)$ & 15.8863(10) & 13.2227(2) & 28.3096(14) & $6.2237(1)$ & $8.2348(3)$ \\
\hline$c(\AA)$ & 29.4693(3) & $29.2987(14)$ & $28.8861(4)$ & $7.9306(4)$ & $15.4551(3)$ & $47.438(2)$ \\
\hline$a\left(^{\circ}\right)$ & 90 & 90 & $82.206(1)$ & 90 & 90 & 90 \\
\hline$\beta\left(^{\circ}\right)$ & $102.281(1)$ & $102.659(4)$ & $86.755(1)$ & 90 & $106.310(1)$ & 90 \\
\hline$Y\left(^{\circ}\right)$ & 90 & 90 & $81.045(1)$ & 90 & 90 & 90 \\
\hline$V(\AA 3)$ & $10567.5(2)$ & $10405.0(10)$ & 2605.62(7) & $2726.1(3)$ & $1648.68(5)$ & $3216.9(2)$ \\
\hline Z & 16 & 16 & 2 & 4 & 4 & 8 \\
\hline$\rho$ calcd $(\mathrm{g} / \mathrm{cm} 3)$ & 1.627 & 1.663 & 1.684 & 1.630 & 2.141 & 2.388 \\
\hline$\mu(m m-1)$ & 0.949 & 1.116 & 1.164 & 1.152 & 8.759 & 8.809 \\
\hline$F(000)$ & 5264 & 5296 & 1340 & 1368 & 1016 & 2176 \\
\hline Goodness-of-fit on F2 & 1.01 & 1.06 & 1.06 & 1.03 & 1.09 & 1.26 \\
\hline Final R1 index $[I>2 \sigma(I)]$ & 0.0444 & 0.0548 & 0.0567 & 0.0412 & 0.0331 & 0.0558 \\
\hline wR2 (all data) & 0.1435 & 0.1825 & 0.1790 & 0.1038 & 0.0952 & 0.1147 \\
\hline $\begin{array}{l}\text { Largest difference in peak } \\
\text { and hole }(\mathrm{e} \AA-3)\end{array}$ & $-0.34,0.70$ & $-0.66,0.67$ & $-1.44,0.69$ & $-0.32,0.79$ & $-1.02,0.77$ & $-0.95,0.74$ \\
\hline
\end{tabular}


Table 2 Selected bond parameters in 1-6

\begin{tabular}{|c|c|c|c|c|c|c|}
\hline COMPLEX & D-H...A & $D-H(\AA ̊)$ & H...A (Å) & D...A (Å) & D - H...A $\left(^{\circ}\right)$ & Symmetry operation \\
\hline \multirow[t]{6}{*}{1} & $\mathrm{~N}(6 \mathrm{~B})-\mathrm{H}(6 \mathrm{~B}) \ldots \mathrm{Cl}(7)$ & 0.86 & 2.49 & $3.337(3)$ & 169 & $x, 1-y, 1 / 2+z$ \\
\hline & $\mathrm{N}(6 \mathrm{C})-\mathrm{H}(6 \mathrm{C}) \ldots \mathrm{Cl}(9)$ & 0.86 & 2.52 & $3.372(3)$ & 169 & \\
\hline & $\mathrm{N}(6 \mathrm{D})-\mathrm{H}(6 \mathrm{D}) \ldots \mathrm{Cl}(7)$ & 0.86 & 2.52 & $3.366(3)$ & 168 & \\
\hline & $\mathrm{N}(7 \mathrm{~B})-\mathrm{H}(7 \mathrm{~B}) \ldots \mathrm{Cl}(7)$ & 0.86 & 2.25 & $3.075(3)$ & 161 & $x, 1-y, 1 / 2+z$ \\
\hline & $\mathrm{N}(7 \mathrm{C})-\mathrm{H}(7 \mathrm{C}) \ldots \mathrm{Cl}(9)$ & 0.86 & 2.29 & $3.120(3)$ & 161 & \\
\hline & $\mathrm{N}(7 \mathrm{D})-\mathrm{H}(7 \mathrm{D}) \ldots \mathrm{Cl}(7)$ & 0.86 & 2.24 & $3.067(3)$ & 161 & \\
\hline \multirow[t]{6}{*}{2} & $\mathrm{~N}(6 \mathrm{~B})-\mathrm{H}(6 \mathrm{~B}) \ldots \mathrm{Cl}(9)$ & 0.86 & 2.48 & $3.330(3)$ & 169 & \\
\hline & $\mathrm{N}(6 \mathrm{C})-\mathrm{H}(6 \mathrm{C}) \ldots \mathrm{Cl}(9)$ & 0.86 & 2.51 & $3.358(3)$ & 168 & $x, 1-y,-1 / 2+z$ \\
\hline & $\mathrm{N}(6 \mathrm{D})-\mathrm{H}(6 \mathrm{D}) \ldots \mathrm{Cl}(7)$ & 0.86 & 2.50 & $3.351(3)$ & 169 & $1 / 2+x,-1 / 2+y, z$ \\
\hline & $\mathrm{N}(7 \mathrm{~B})-\mathrm{H}(7 \mathrm{~B}) \ldots \mathrm{Cl}(9)$ & 0.86 & 2.26 & $3.087(3)$ & 161 & \\
\hline & $\mathrm{N}(7 \mathrm{C})-\mathrm{H}(7 \mathrm{C}) \ldots \mathrm{Cl}(9)$ & 0.86 & 2.26 & $3.086(3)$ & 161 & $x, 1-y,-1 / 2+z$ \\
\hline & $\mathrm{N}(7 \mathrm{D})-\mathrm{H}(7 \mathrm{D}) \ldots \mathrm{Cl}(7)$ & 0.86 & 2.32 & $3.137(3)$ & 159 & $1 / 2+x,-1 / 2+y, z$ \\
\hline \multirow[t]{8}{*}{3} & $N(6 A)-H(6 A) \ldots C l(2)$ & 0.86 & 2.50 & $3.345(5)$ & 168 & \\
\hline & $\mathrm{N}(6 \mathrm{~B})-\mathrm{H}(6 \mathrm{~B}) \ldots \mathrm{Cl}(1)$ & 0.86 & 2.50 & $3.346(4)$ & 169 & \\
\hline & $\mathrm{N}(6 \mathrm{C})-\mathrm{H}(6 \mathrm{C}) \ldots \mathrm{Cl}(1)$ & 0.86 & 2.51 & $3.352(5)$ & 169 & \\
\hline & $\mathrm{N}(6 \mathrm{D})-\mathrm{H}(6 \mathrm{D}) \ldots \mathrm{Cl}(2)$ & 0.86 & 2.48 & $3.328(5)$ & 169 & $1-x,-y, 1-z$ \\
\hline & $N(7 A)-H(7 A) \ldots C l(2)$ & 0.86 & 2.24 & $3.064(5)$ & 161 & \\
\hline & $\mathrm{N}(7 \mathrm{~B})-\mathrm{H}(7 \mathrm{~B}) \ldots \mathrm{Cl}(1)$ & 0.86 & 2.29 & $3.113(5)$ & 160 & \\
\hline & $\mathrm{N}(7 \mathrm{C})-\mathrm{H}(7 \mathrm{C}) \ldots \mathrm{Cl}(1)$ & 0.86 & 2.29 & $3.116(5)$ & 160 & \\
\hline & $\mathrm{N}(7 \mathrm{D})-\mathrm{H}(7 \mathrm{D}) \ldots \mathrm{Cl}(2)$ & 0.86 & 2.24 & $3.066(5)$ & 161 & $1-x,-y, 1-z$ \\
\hline \multirow[t]{4}{*}{4} & $\mathrm{~N}(6 \mathrm{~A})-\mathrm{H}(6 \mathrm{~A}) \ldots \mathrm{Cl}(4)$ & 0.86 & 2.46 & $3.304(5)$ & 167 & $-1+x, y, z$ \\
\hline & $\mathrm{N}(6 \mathrm{~B})-\mathrm{H}(6 \mathrm{~B}) \ldots \mathrm{Cl}(5)$ & 0.86 & 2.52 & $3.368(5)$ & 167 & $-1+x, y, z$ \\
\hline & $\mathrm{N}(7 \mathrm{~A})-\mathrm{H}(7 \mathrm{~A}) \ldots \mathrm{Cl}(4)$ & 0.86 & 2.27 & $3.079(4)$ & 157 & $-1+x, y, z$ \\
\hline & $\mathrm{N}(7 \mathrm{~B})-\mathrm{H}(7 \mathrm{~B}) \ldots \mathrm{Cl}(5)$ & 0.86 & 2.23 & $3.055(4)$ & 161 & $-1+x_{1}, y, z$ \\
\hline \multirow[t]{2}{*}{5} & $N(1)-H(1) \ldots B r(3)$ & 0.86 & 2.50 & $3.238(2)$ & 145 & $x, 3 / 2-y,-1 / 2+z$ \\
\hline & $N(9)-H(9) \ldots N(3)$ & 0.86 & 2.09 & $2.898(4)$ & 156 & $-x, 2-y,-z$ \\
\hline \multirow[t]{2}{*}{6} & $N(6)-H(6) \ldots B r(2)$ & 0.86 & 2.85 & 3.683(8) & 165 & $x_{1} 1+y_{1} z$ \\
\hline & $N(7)-H(7) \ldots B r(2)$ & 0.86 & 2.64 & $3.451(8)$ & 158 & $x, 1+y, z$ \\
\hline
\end{tabular}<smiles></smiles>

(a)

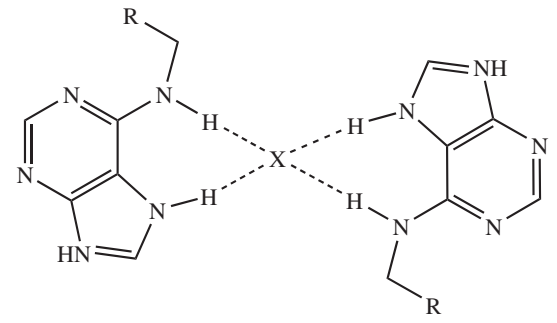

(c)

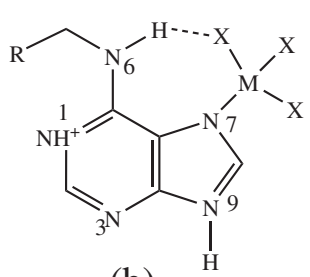

(b)

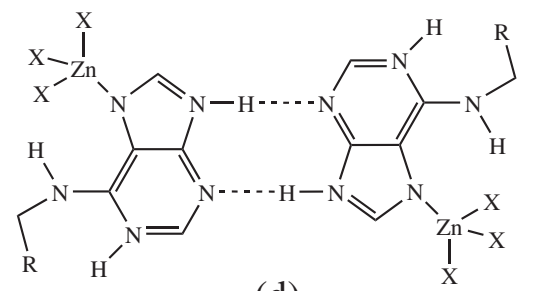

(d)

Scheme 1 In (a-d) $X=C l-, B r-$. (a-c) $R=C_{6} H_{5}$ for $B A / C_{4} H_{3} O$ for FA. (d) $\mathrm{R}=\mathrm{C}_{6} H_{5}$ for $B A$. 


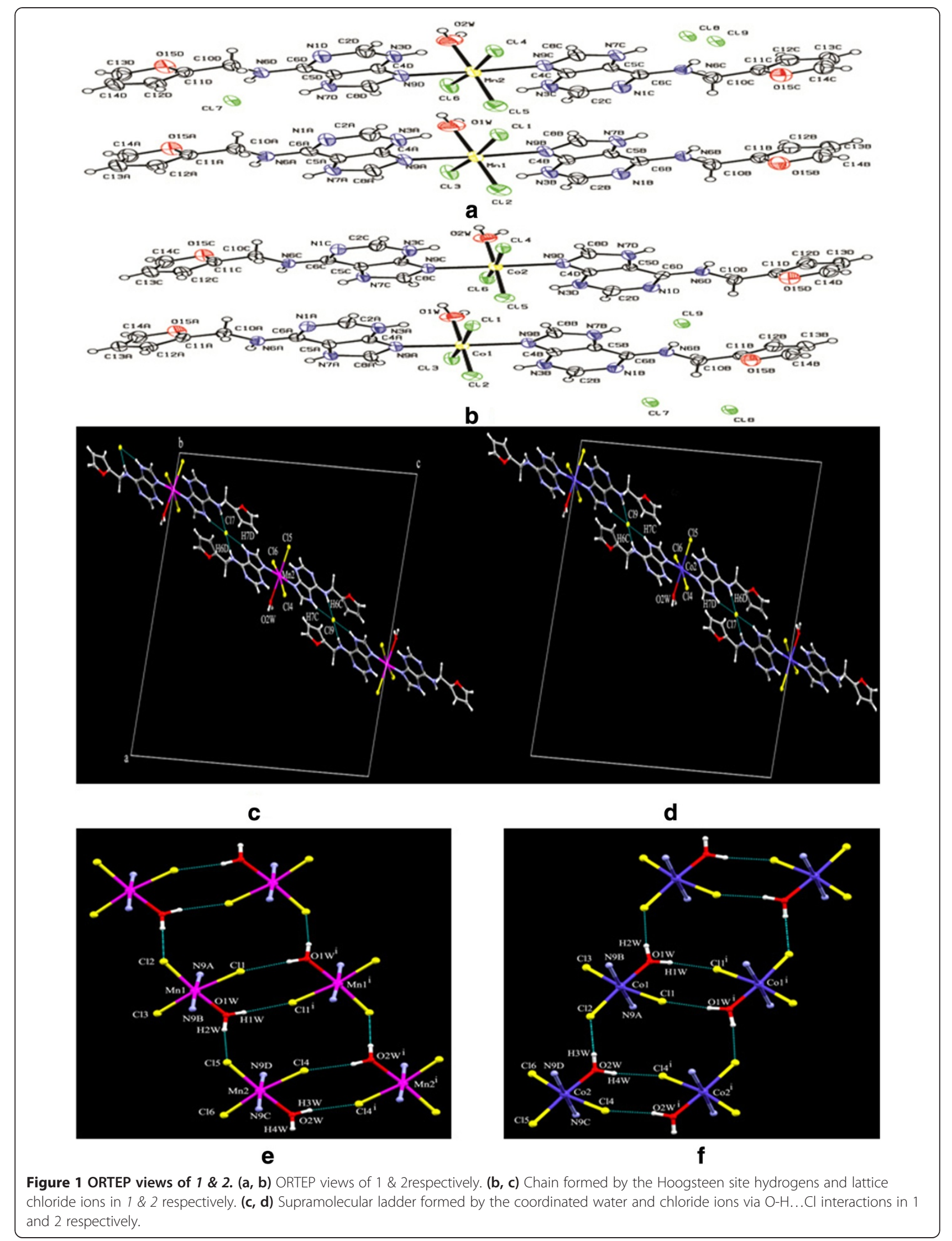


benzyladenine and 4 drops of conc. $\mathrm{HBr}$ were added to this solution and heated to $60 \mathrm{~min}$. The resultant solution was allowed to slow evaporation at room temperature. After a few days pale green crystals of (5) were obtained.

Preparation of catena-Poly [ $\mu$-bromido bis(benzyladeninN1$H$ ium) di cadmium (II) tri - $\mu$-bromido] (BACDBR) (6)

$40 \mathrm{ml}$ aqueous solution of $\mathrm{CdBr}_{2} \cdot 4 \mathrm{H}_{2} \mathrm{O}$ (0.0861 g) was heated at $55^{\circ} \mathrm{C}$ for $30 \mathrm{~min}$. over a magnetic stirrer. $0.0563 \mathrm{~g}$ of benzyladenine and 4 drops of conc. $\mathrm{HBr}$ were added to this solution and heated to $60 \mathrm{~min}$. The resultant solution was allowed to slow evaporation at room temperature. After a few days pale green crystals of (6) were obtained .

\section{Crystal structure determination}

Intensity data sets were collected at room temperature, on a BRUKER SMART APEXII CCD [25] area-detector diffractometer equipped with graphite monochromated Mo $K \alpha$ radiation $(\lambda=0.71073 \AA)$. The data were reduced by using the program SAINT [25] and empirical absorption corrections were done by using the SADABS [25]. The structures were solved by direct methods using SHELXS-97 [26] and subsequent Fourier analyses, refined anisotropically by full-matrix least-squares method using SHELXL-97 [26] within the WINGX suite of software, based on F2 with all reflections. All carbon hydrogens were positioned geometrically and refined by a riding model with Uiso 1.2 times that of attached atoms. All non $\mathrm{H}$ atoms were refined anisotropically. The molecular structures were drawn using the ORTEP-III [27] and MERCURY [28]. Crystal data and the selected parameters for compounds (1-6) were summarized in (Tables 1 and 2) respectively. The crystals remained stable throughout the data collection.

\section{Results and discussion}

Single crystal $x$-ray diffraction studies reveal that (1) and (2) are isomorphous structures. The cytokinins in complexes (1-4), are N3 protonated, N9 coordinated and N7-H tautomer, but in (5) it is N1-protonated, N7 coordinated and N9-H tautomer. This can be confirmed from the bond angle difference between the N9-H neutral kinetin, benzyladenine structures and their protonated compounds [29,30]. Axially coordinated adenine ligand moieties are arranged in a trans manner with respect to the central axis (passing through the N9 atoms and metal) in the compounds (1-4). Also the dihedral angle between the adenine ring and the N6-substituent aromatic ring shows the compounds all are active cytokinins [31].

A lattice halide ion bridges N6-H and N7-H (Hoogsteen site hydrogens) [32,33] via. N-H...X hydrogen bonds [shown schematically in Scheme 1c] which lead to a chain like pattern in the crystals (1-4). A centrosymmetric base pair is formed due to the pairing of N3 and N9-H hydrogen bonds in (5) (Scheme 1d). Coordination spheres are arranged as a ladder by the coordinated chloride ion and water in structures (1-3) (only Co1 of 3). Ladders of (1-3) have a similar type of hydrogen bonds and atomic arrangements. There is no such ladder type pattern observed in $\mathrm{Co} 2$ and $\mathrm{Co} 3$ cobalt centers of (3) due to the absence of water molecule in the coordination sphere. An intra molecular S(6) ring motif is formed by N3 hydrogens with the halide ions in all the crystal structures.

\section{Crystal structure description of [FAMNCL] 1 \& Crystal structure description of [FACOCLI] 2}

The asymmetric unit of (1) as well as (2) consists of two metal centers with similar distorted octahedral coordination geometry (made up of two furfuryladenine cations, three chloride ions and a water molecule). A lattice chloride ion lies at general position and two lattice chloride ions are present in special position (each with 0.5 occupancy).

The special position chloride ions ( $\mathrm{Cl} 7$ and $\mathrm{Cl} 8$ for complex (3) where as $\mathrm{Cl} 8$ and $\mathrm{Cl} 9$ for complex (3)) are positioned at e 2 Wyckoff site symmetry [34-36]. The Hoogsteen site hydrogens are involved in $\mathrm{N}-\mathrm{H}$...Cl
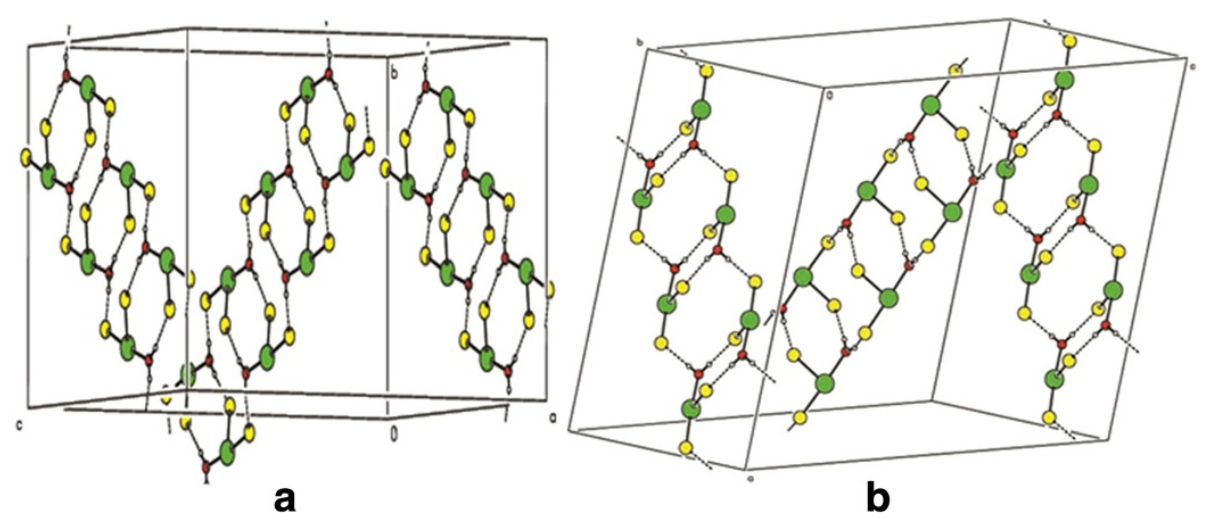

Figure 2 The scissoring arrangement of supramolecular ladders. a, b) The scissoring arrangement of supramolecular ladders in 1 and 2 respectively 


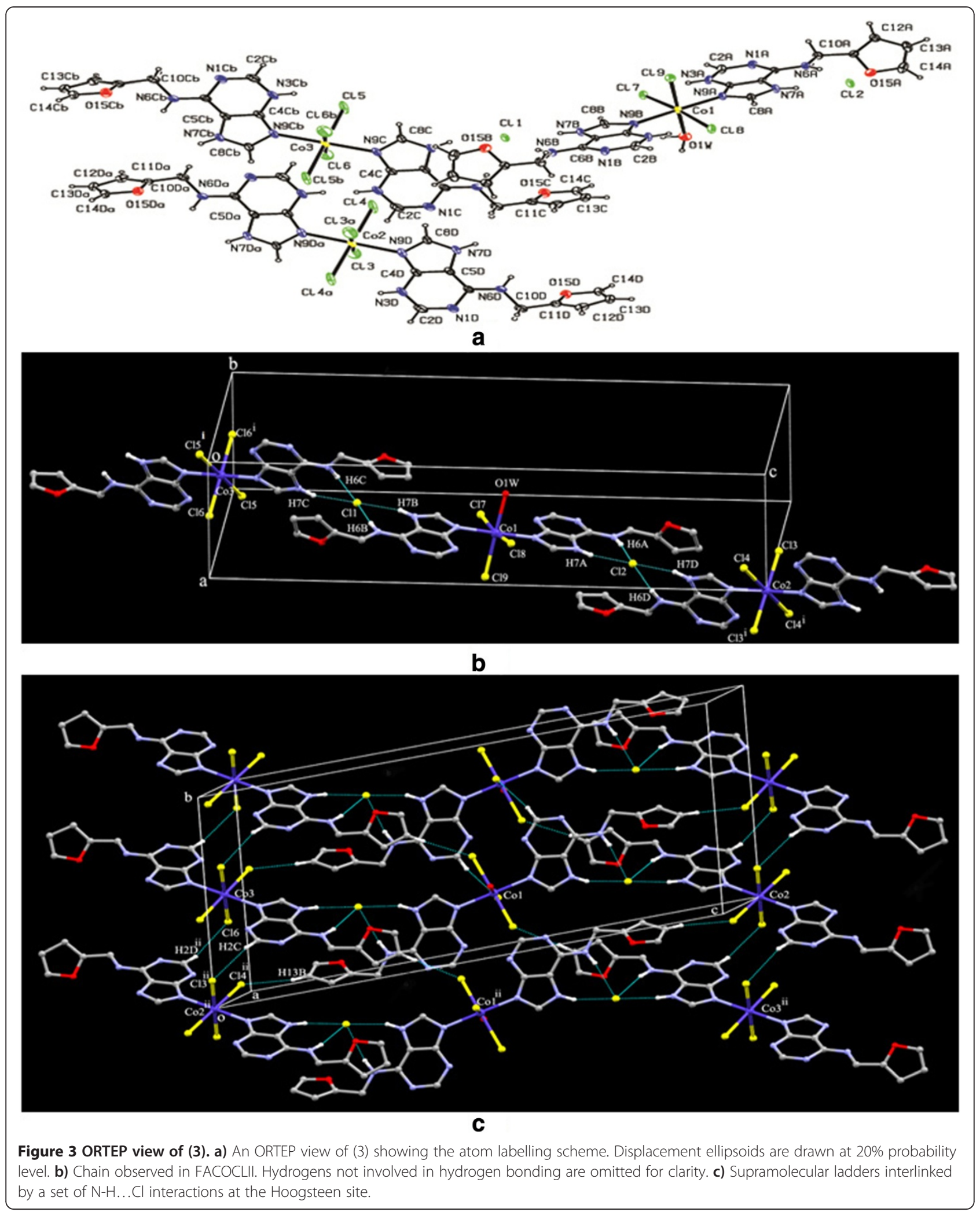


hydrogen bonds with the lattice chloride ion which leads to a chain like pattern in the crystal structures (1) and (2) respectively (Figure 1c,d). Crystal structure (1) contains cobalt ion and (2) contains manganese ion as metal centers, but all other groups are similar in the asymmetric unit. The inter ligand interactions involving the chloride ions and the water molecules generate a ladder like pattern (Figure 1c,d). In the ladder M1 and M2 metal centers (Mn1and Mn2 for (1) and Co1 and Co2 for (2)) are arranged alternatively (Figure 1e,f).

In these supramolecular ladders the coordinated water and coordinated chloride ions in the structures (1) and (2) form $\mathrm{R}_{4}{ }^{4}(12)$ and $\mathrm{R}_{2}{ }^{2}$ (8) ring motifs made up of $\mathrm{O}$ $\mathrm{H}$...Cl interactions. Perpendicular to the $\mathrm{R}_{2}{ }^{2}(8)$ motif, $R_{3}^{2}(9)$ motif is made by the same chloride and water with adenine ring N3 \& $\mathrm{C} 2$ hydrogens. The ladders are arranged in a scissoring arrangement in the packing pattern of the crystal structures (1) and (2) respectively (Figure 2a,b). The supramolecular chains are connected by supramolecular ladders and this leads to a three dimensional network which is also further stabilized by the $\mathrm{C} 10-\mathrm{H} . . . \mathrm{Cl}$ interactions in both $(\mathbf{1}, \mathbf{2})$.

\section{Crystal structure description of [FACOCLII] 3}

The asymmetric unit consists of three mononuclear cobalt centers and two lattice chloride ions. All the three Co centers have a distorted octahedral geometry. Two of the cobalt centers (each on an inversion center) have similar coordination geometry made up of two chloride ions, one furfuryladenine cation and their inversion related ligands (Figure 3a). They are (Co2 and $\mathrm{Co} 3$ ions) positioned at $a \overline{1}$ and $e \overline{1}$ Wyckoff site symmetries respectively. Unlike these $\mathrm{Co} 2$ and $\mathrm{Co} 3$ ions, Co1 ion lies at the general position (surrounded by the two furfuryladenine cations, three chloride ions and a hydronium ion). This cobalt center (Co1) also forms $\mathrm{R}_{4}{ }^{4}(12), \mathrm{R}_{2}{ }^{2}(8), \mathrm{R}_{3}{ }^{2}(9)$ and the ladder type arrangement, which is similar to that of crystals (1) and (2), which is the unique character observed in Co1 and not in $\mathrm{Co} 2$ or $\mathrm{Co} 3$ centre. A supramolecular chain is formed by the Hoogsteen site hydrogens and a lattice chloride ion. In this chain the cobalt centers are arranged as (-Co2-Co1-Co3-Co1-Co2-Co1-Co3-) n revealing the alternative arrangement of $\mathrm{Co} 1$ inbetween ( $\mathrm{Co} 2$ and $\mathrm{Co} 3)$ as well as (Co3 and Co2) (Figure 3b). Supramolecular ladders are interlinked by a set of $\mathrm{N}-\mathrm{H} . . . \mathrm{Cl}$ interactions at the Hoogsteen site. (Fig3.3c).

\section{Crystal structure description of (FANICL) 4}

The asymmetric unit consists of a cobalt ion with distorted octahedral coordination geometry, coordinated to two furfuryladenine cations and two chloride ions equatorially, a chloride ion and a water molecule axially (Figure 4).

In the lattice, two chloride ions with 0.5 occupancy and a water molecule are present. The $\mathrm{N}-\mathrm{H}$...Cl interactions found in between the Hoogsteen site hydrogen and lattice chloride ion generates a chain which is also observed in (1-3) (Figure 5). Two of the metal centers are connected by a O-H...O,C-H..Cl and two O-H...Cl interactions inbetween a coordinated water molecule, lattice water molecule and two of the coordinated chloride ions (Figure 5). One of the lattice water hydrogen is involved in bifurcated hydrogen bond with two coordinated chloride ions forming a $\mathrm{R}_{1}^{2}(4)$ motif. The $\mathrm{C}-\mathrm{H}$...Cl interaction is present inbetween the $\mathrm{C} 2$ hydrogen of the coordinated furfuryl adenine and the chloride of the next cobalt centre. O-H...O, two C-H...Cl, two O-H...Cl and

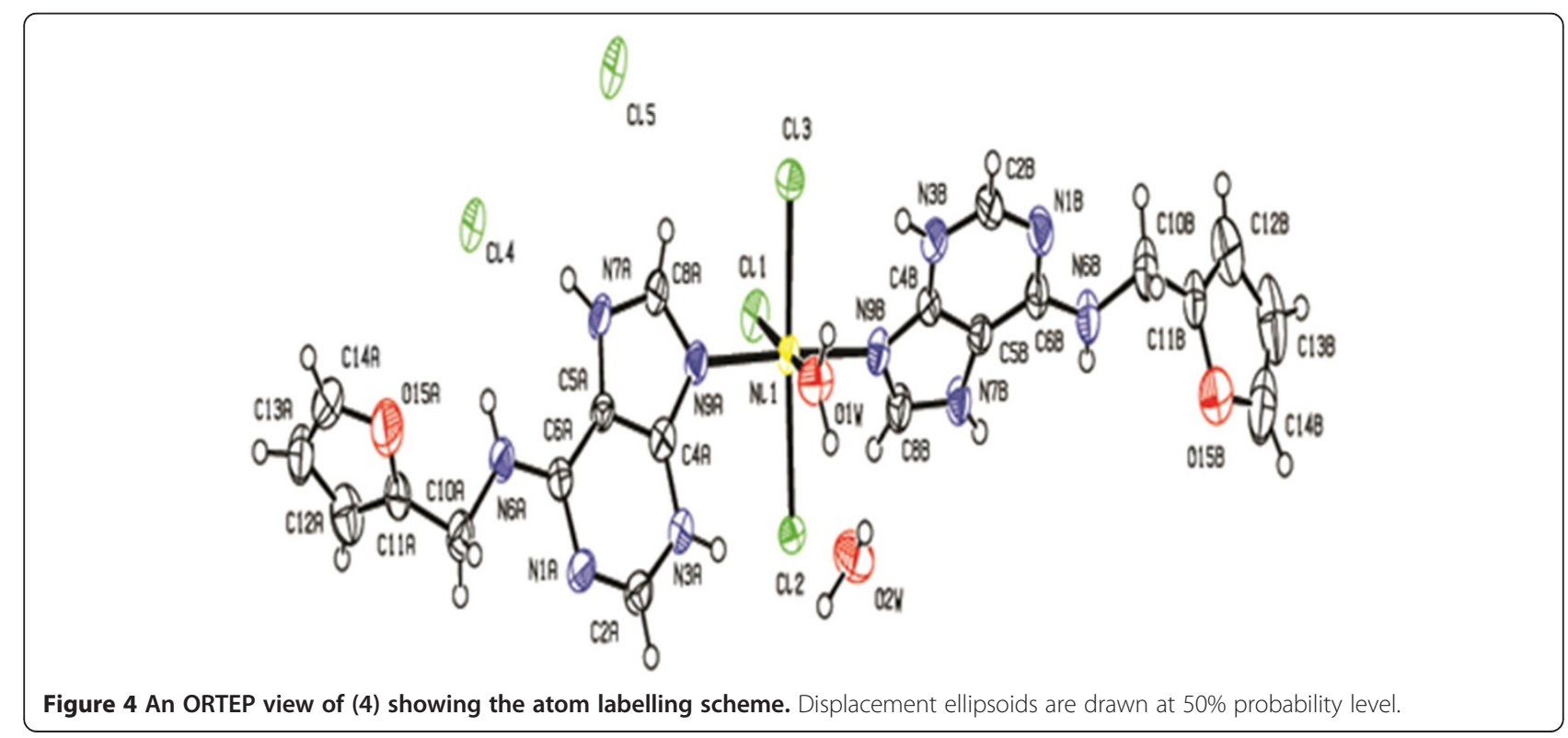




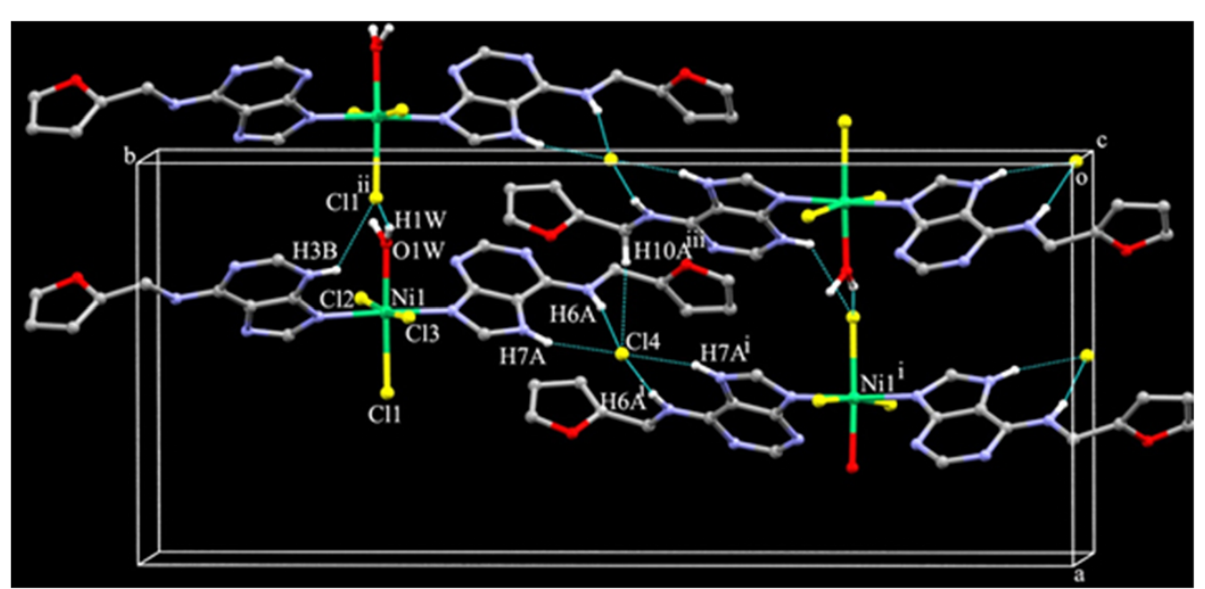

Figure 5 The metal centers connected by a O-H...O,C-H..Cl and two O-H...Cl interactions as well as Chain formed by $\mathrm{N}-\mathrm{H} . . . \mathrm{Cl}$ interactions in between the Hoogsteen site hydrogen and lattice chloride ion.

$\mathrm{N}-\mathrm{H} . . . \mathrm{Cl}$ interactions generates a three dimensional network by connecting two of these chains (Figure 5).

Crystal structure description of [Zn(BAH+)Br3] (BAZNBR) 5 The asymmetric unit consists of a zinc(II) metal center, terahedrally coordinated to benzyladeninium cation $\left(\mathrm{BAH}^{+}\right)$ and three bromide ions. The $\mathrm{BAH}^{+}$is a N7-coordinated; $\mathrm{N} 1$ protonated; N9-H tautomer (Figure 6).

The Br1 interchelated by the N6-H atom through $\mathrm{N}$ $\mathrm{H}$...Br hydrogen bond forms a S(7) motif. The N1 and C2 atoms form hydrogen bonds with two different bromide ions leading to a $\mathrm{R}_{2}{ }^{2}(7)$ ring motif. The continuous formation of $\mathrm{R}_{2}{ }^{2}(7)$ ring motif extends a chain along $\mathrm{c}$ axis (Figure 7a). In this chain adjacent adenine moieties are in different planes and forming a N-H...N base pair with two different chain adenine moieties, but alternate adenine moieties; are in same plane and form a base pair with the same chain adenine moieties (Figure 7a).

$\mathrm{R}_{6}{ }^{6}(34)$ ring motif is formed between these two chains through the N-H... Br and C-H... Br bonds (Figure 7b).

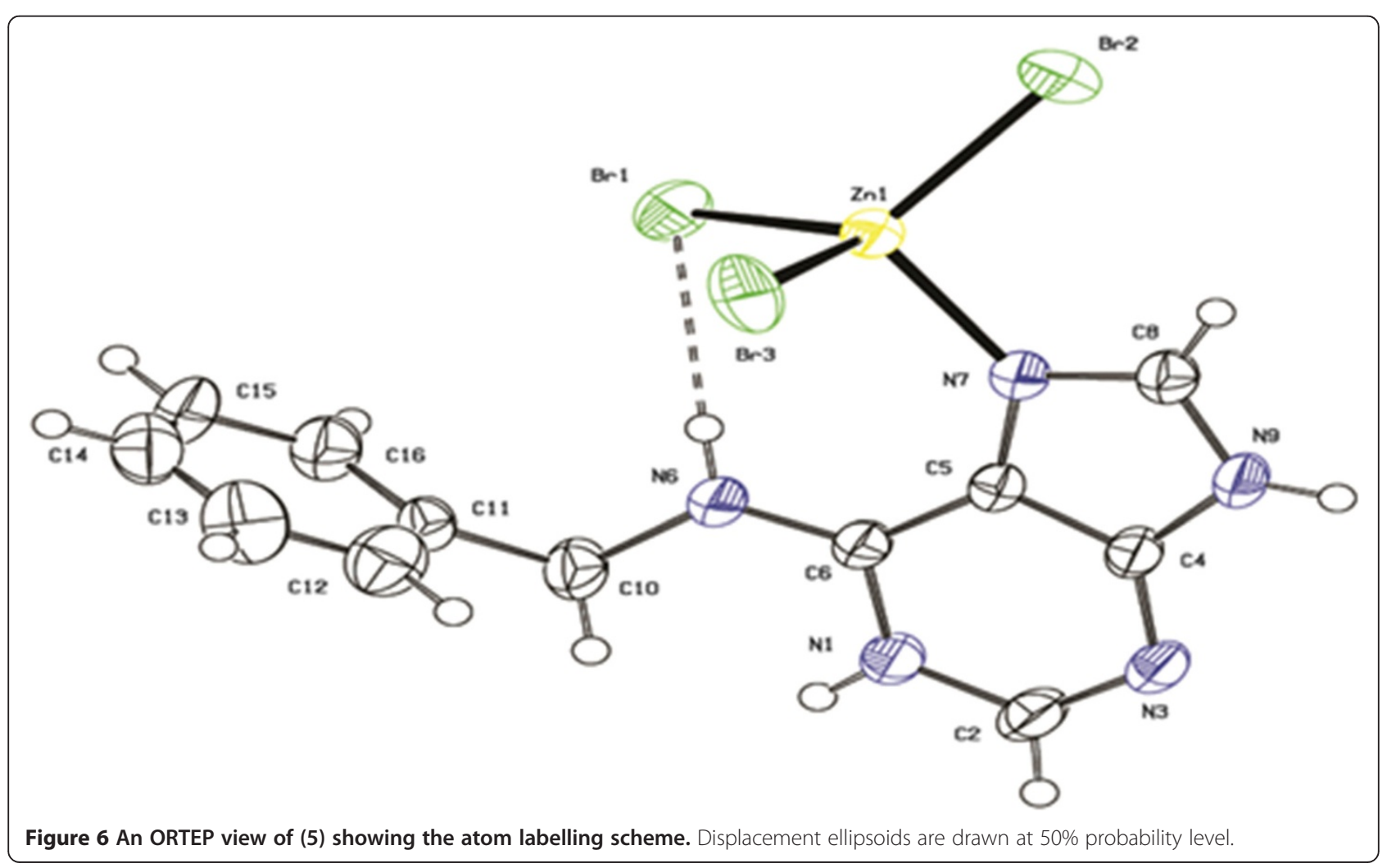




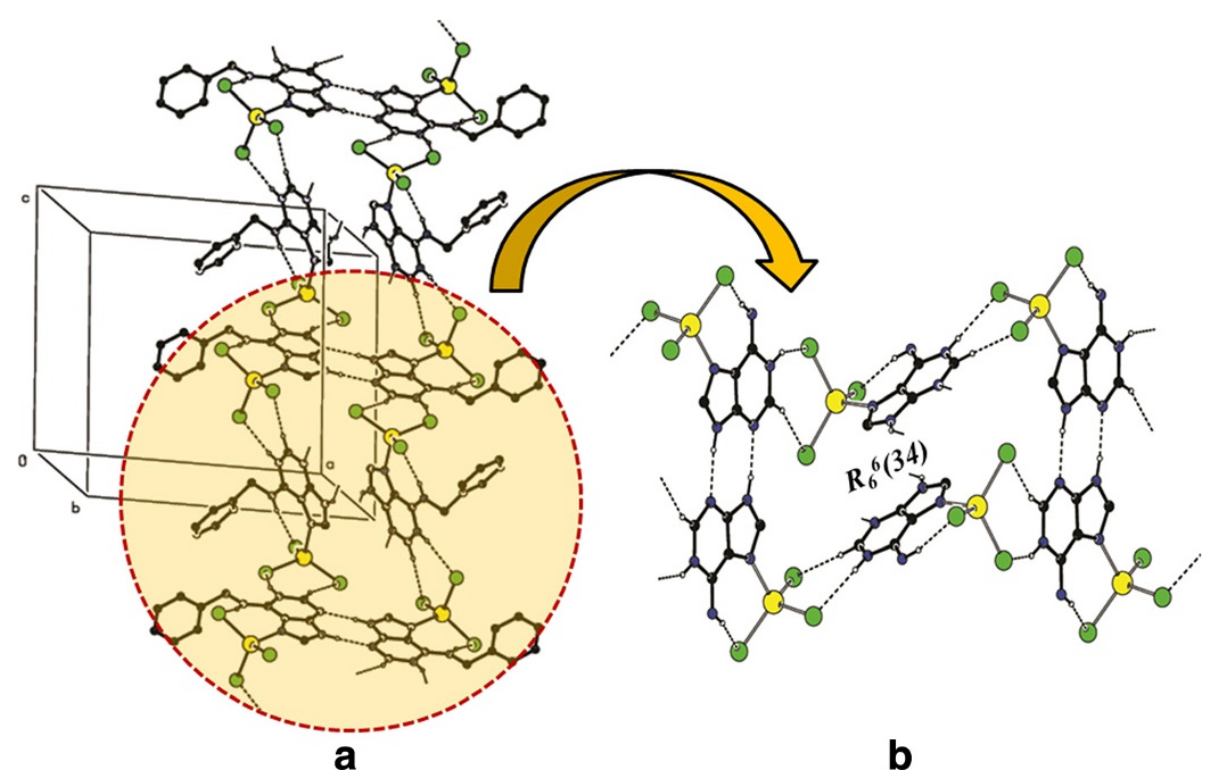

Figure 7 The formation of $\mathbf{N}-\mathrm{H}$...N base pair. a) The formation of $\mathrm{N}-\mathrm{H} \ldots \mathrm{N}$ base pair between alternative adenine moieties which lie in same plane. b) $\mathrm{R}_{6}{ }^{6}(34)$ ring motif is formed between two chains through the $\mathrm{N}-\mathrm{H} \ldots \mathrm{Br}$ and $\mathrm{C}-\mathrm{H} \ldots \mathrm{Br}$ bonds.

A single chain is connected through base pair with two different chains. These two chains are further connected to different chains and so on, generating three dimensional networks. (Figure 8a). The phenyl rings of symmetry related molecules are stacked with one another giving additional stabilization to the structure (Figure $8 \mathrm{~b}$ ).

\section{Crystal structure description of (BACDBR) 6}

The crystal structure of (6) is a coordination polymer and it consists of two cadmium centers bridged by three bromide ions. Each of the cadmium center is six coordinated by five bromide and one benzyadeninium cation $\left(\mathrm{BAH}^{+}\right)$(Figure 9). Each of the dicadmium centers are linked to each other by a bromide ion and this extends the structure into a coordination polymer (Figure 10a).

The cadmium ions in this dicadmium center are separated by the distance of $3.467 \AA$. In this polymeric chain, all $\mathrm{BAH}^{+}$ions are arranged in one side. The chains are connected by the $\mathrm{Br} 2$ bromide ions and the Hoogsteen site hydrogens via $\mathrm{N}-\mathrm{H} . . \mathrm{Br}$ hydrogen bonds (Figure 10b). Polymeric chain interlinks generate "V" shaped arrangement repeatedly in the network. Each cadmium has one bromide ion, which is not involved in bridging, which forms a S(6) intramolecular ring motif with the N3 hydrogen of $\mathrm{BAH}^{+}$. C-H...Br interaction is found between $\mathrm{C} 15$ hydrogen of the phenyl ring and the $\mathrm{Br} 4$. A

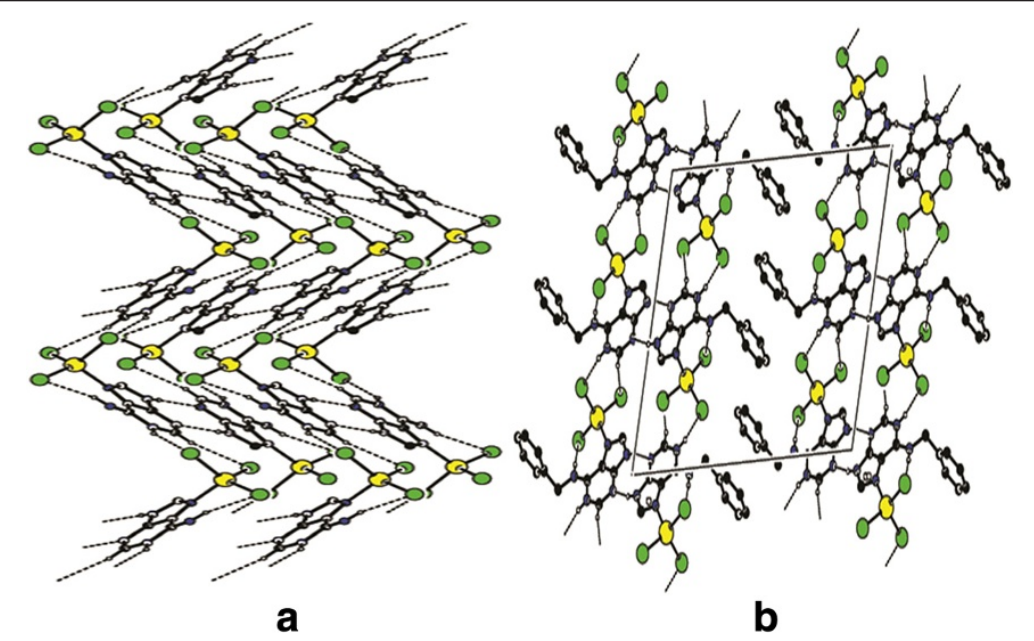

Figure 8 The base pair connecting the successive chains. a) The base pair connecting the successive chains leading to a three dimensional network. The benzyl substituents are omitted for clarity. b) The stacking between the phenyl rings of the adenine moieties along $b$ axis. 


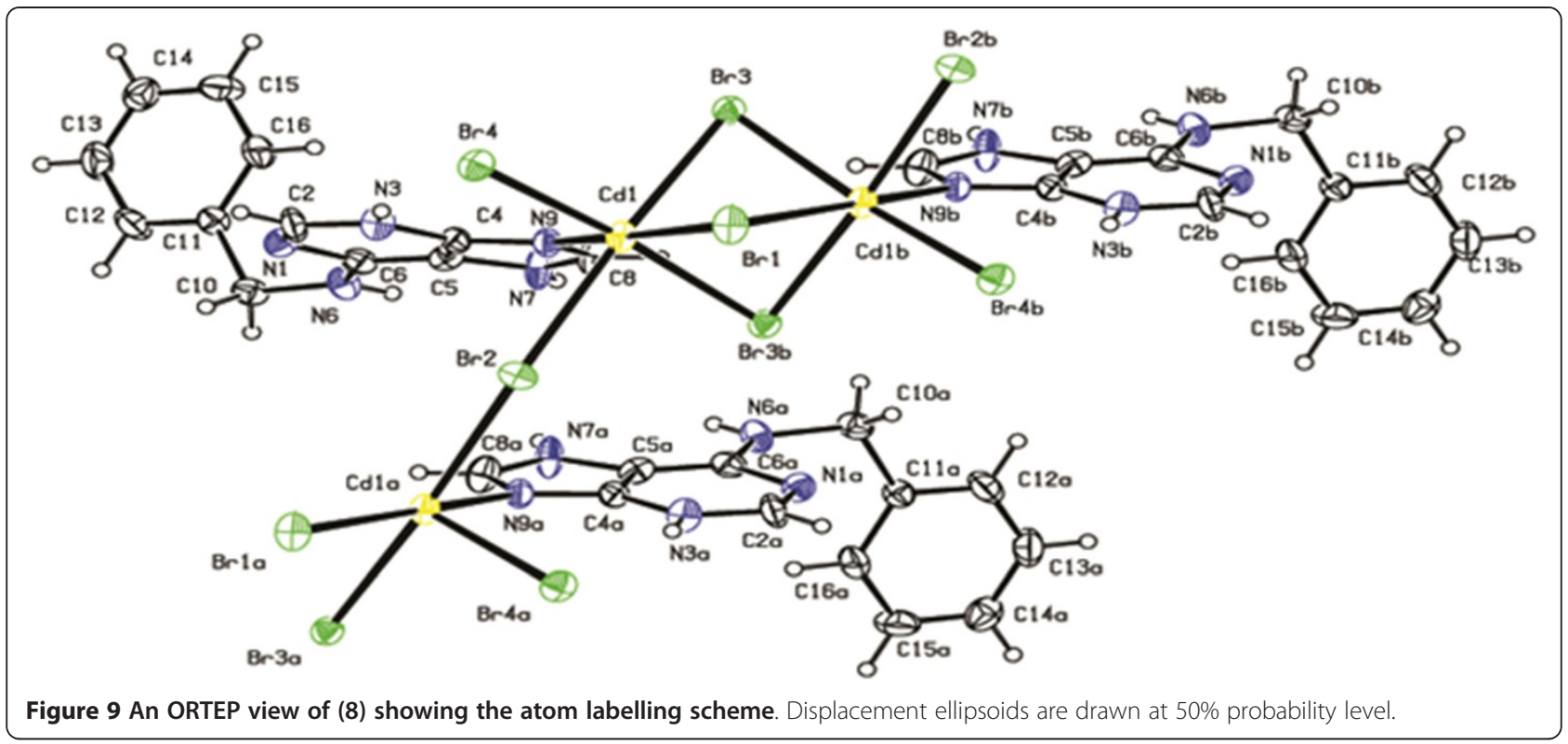

weak $\mathrm{C}-\mathrm{H} . . . \pi$ interaction is observed between $\mathrm{C} 2$ hydrogen and phenyl ring of the $\mathrm{BAH}^{+}$(Figure 10c). Three dimensional network of the crystal structure viewed along c axis is shown in (Figure 10d).

\section{Conclusion}

We have obtained a series of metal complexes of N6furfuryl adenine/N6-benzyl adenine. Of these six, five are mononuclear while the one is a coordination polymer. Complexes show two different coordination geometries like distorted octahedral in 1-4, 6 and tetrahedral in 5). In complexes (1-4) the primary supramolecular organization remain common which is a chain made up of $\mathrm{N}-\mathrm{H}$...Cl interactions inbetween the Hoogsteen sites hydrogen and a Chloride anion lying at the lattice. These crystal structures show several supramolecular motifs,

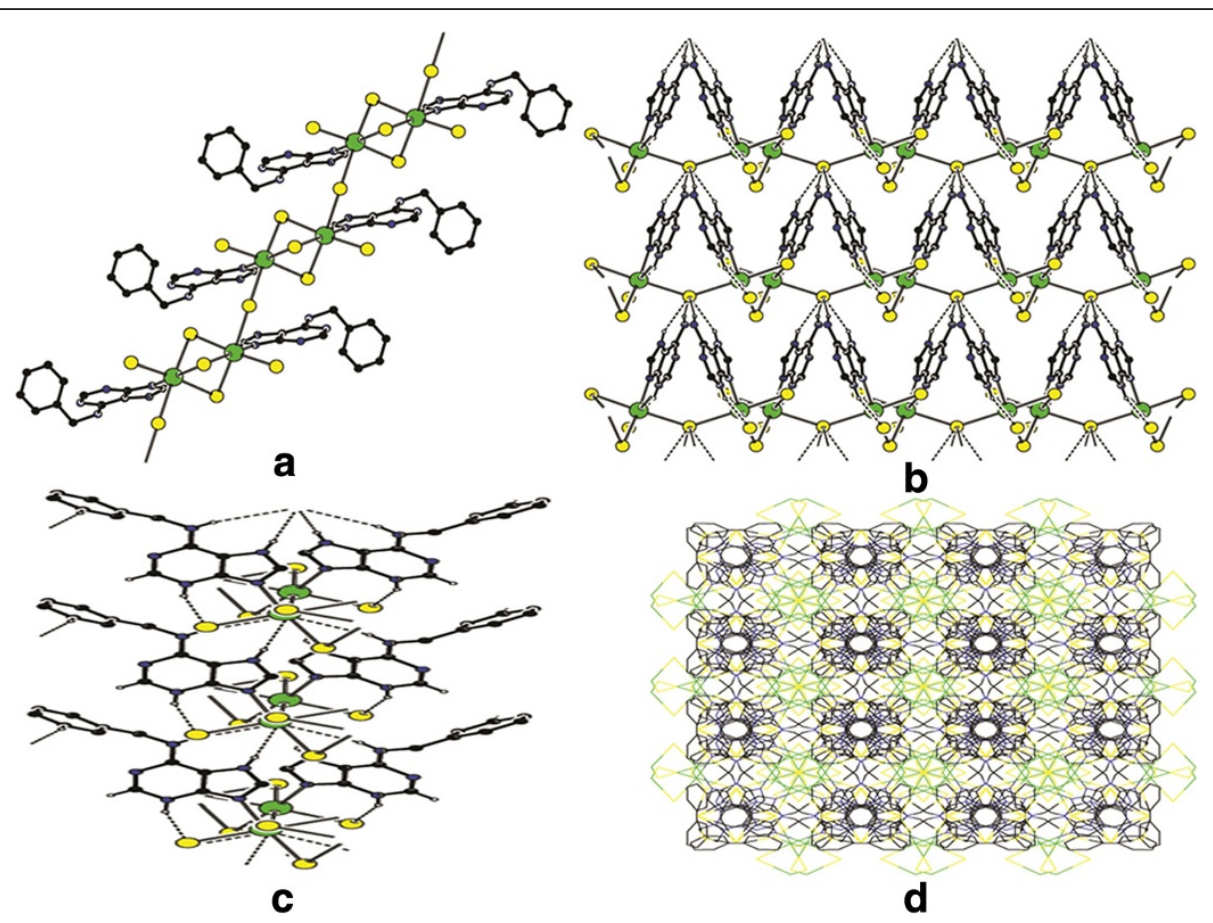

Figure 10 Coordination polymer formed by the monobridged bromide ion. a) Coordination polymer formed by the monobridged bromide ion $\left(\mathrm{Br}_{2}\right)$ linking the dicadmium center. b) Coordination polymeric chains linked by the Hoogsteen site hydrogens and monobridged $\mathrm{Br}_{2}$ ions via $\mathrm{N}-\mathrm{H}$... Br hydrogen bonds. c) $\mathrm{C}-\mathrm{H} \ldots \pi$ interaction between $\mathrm{C} 2$ hydrogen and the phenyl ring of $\mathrm{BAH}+$. d) Formation of three dimensional networks viewed along $\mathrm{c}$ axis. 
stacking patterns, preferred site of protonation/coordination, etc., in these kinds of complexes. This piece of work may also help in study of similar type complexes which may eventually lead to novel functional materials.

\section{Supplementary material}

CCDC 1005990-1005993, 1005996 and 1005997 contain the supplementary crystallographic data for structures (16) respectively can be obtained free of charge via http:// www.ccdc.cam.ac.uk/Community/Requestastructure/Pages/ DataRequest.aspx?, or from the Cambridge Crystallographic Data Center, 12 Union Road, Cambridge CB2 IEZ, UK; fax:(+44)1223-336-033; or e-mail: deposit@ccdc.cam.ac.uk.

\section{Competing interests}

The authors declare that they have no competing interests.

\section{Authors' contributions}

This work was prepared in the research group of PTM. He proposed the work and drafted the manuscript. SJJ, DTS participated in the design and presiding the experiments, collected the X-ray data and drafted the manuscript. All authors read and approved the final manuscript.

\section{Acknowledgements}

The authors thank the DST India (FIST programme) for the use of the X-ray diffractometer at the School of Chemistry, Bharathidasan University, Tiruchirappalli, Tamilnadu, India. PTM thank the UGC-BSR for the award of one-time grant.

Received: 2 June 2014 Accepted: 2 September 2014

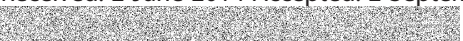

\section{References}

1. Jenniefer SJ, Muthiah PT: Supramolecular architectures of two novel organic-inorganic hybrid materials containing identical monomeric uranyl units. Acta Cryst C 2011, 67:m69-m72.

2. Hoffmann F, Cornelius M, Morell J, Fröba M: Silica-based mesoporous organic-inorganic hybrid materials. Angew Chem Int Ed 2006, 45:3216-3251.

3. Lee SJ, Lin W: Chiral metallocycles: rational synthesis and novel applications. Acc Chem Res 2008, 41:521-537.

4. Lu WG, Jiang L, Feng $X L$, Lu TB: Three-dimensional lanthanide anionic metal - organic frameworks with tunable luminescent properties induced by cation exchange. Inorg Chem 2009, 48:6997-6999.

5. Tagami H, Uchida S, Mizuno N: Inorganic hybrids size-selective sorption of small organic molecules in One-dimensional channels of an ionic crystalline organic-inorganic hybrid compound stabilized by $\pi-\pi$ interactions. Angew Chem Int Ed 2009, 48:6160-6165.

6. Alkordi MH, Brant JA, Wojtas L, Kravtsov VC, Cairns AJ, Eddaoudi M: Zeolite-like metal - organic frameworks (ZMOFs) based on the directed assembly of finite metal - organic cubes (MOCs). J Am Chem Soc 2009, 131:17753-17755.

7. Kalnicova A, Travnicek Z, Popa I, Cajan M, Dolezal K: Synthesis, characterization and in vitro cytotoxicity of $\mathrm{Co}$ (II) complexes with N6-substituted adenine derivatives: X-ray structures of 6-(4-chlorobenzylamino)purin-di-ium diperchlorate dihydrate and $\left[\mathrm{Co}_{6}\left(\mu-\mathrm{L}_{6}\right) 4 \mathrm{Cl}_{8}(\mathrm{DMSO})_{10}\right] \cdot 4 \mathrm{DMSO}$. Polyhedron 2006, 25:1421.

8. Trávníček Z, Klanicová A, Popa I, Rolčík J: Synthetic, spectral, magnetic and in vitro cytotoxic activity studies of cobalt (II) complexes with cytokinin derivatives: X-ray structure of 6-(3-methoxybenzylamino) purinium chloride monohydrate. J Inorg Biochem 2005, 99:776-786.

9. Maloň M, Trávníček Z, Maryško M, Zbořil R, Mašláň M, Marek K, Dolezel, Rolcik J, Krystof V, Strnad M: Metal complexes as anticancer agents 2. Iron (III) and copper(II) bio-active complexes with N6-benzylaminopurine derivatives. Inorg Chim Acta 2001, 323:119-129.

10. Štarha P, Trávníček Z, Herchel R, Popa I, Suchý P, Vančo J: Dinuclear copper (II) complexes containing 6-(benzylamino)purines as bridging ligands: Synthesis, characterization, and in vitro and in vivo antioxidant activities. J Inorg Biochem 2009, 103:432-440.
11. Travnicek Z, Malon M, Sindelar Z, Dolezal K, Rolcik J, Krystof V, Strnad M, Marek J: Preparation, physicochemical properties and biological activity of copper(II) complexes with 6-(2-chlorobenzylamino)purine $\left(\mathrm{HL}_{1}\right)$ or 6-(3-chlorobenzylamino)purine $\left(\mathrm{HL}_{2}\right)$. The single-crystal $\mathrm{X}$-ray structure of $\left[\mathrm{Cu}\left(\mathrm{H}^{+} \mathrm{L}_{2}\right)_{2} \mathrm{Cl}_{3}\right] \mathrm{Cl} \cdot 2 \mathrm{H}_{2} \mathrm{O}$. J Inorg Biochem 2001, 84:23-32.

12. Trávníček Z, Maloň M, Zatloukal M, Doležal K, Strnad M, Marek J: Mixed ligand complexes of platinum(II) and palladium(II) with cytokinin-derived compounds Bohemine and Olomoucine: $\mathrm{X}$-ray structure of $\left[\mathrm{Pt}\left(\mathrm{BohH}+-\mathrm{N}_{7}\right)\right.$ $\left.\mathrm{Cl}_{3}\right] \cdot 9 / 5 \mathrm{H}_{2} \mathrm{O}$ \{Boh = 6-(benzylamino)-2-[(3-(hydroxypropyl)-amino]-9isopropylpurine. Bohemine\}. J Inorg Biochem 2003, 94:307-316.

13. Trávníček Z, Popa I, Čajan M, Zbořil R, Kryštof V, Mikulík J: The first iron(III) complexes with cyclin-dependent kinase inhibitors: Magnetic, spectroscopic (IR, ES + MS, NMR, ${ }^{57}$ Fe Mössbauer), theoretical, and biological activity studies. J Inorg Biochem 2010, 104:405-417.

14. Trávníček Z, Maloň M, Biler M, Hajdúch M, Brož P, Doležal K, Strnad M Synthesis, characterization and biological activity of two nickel (II) complexes with 6-(2-chlorobenzylamino) purine. Trans Met Chem 2000, 25:265-269.

15. Trávníček Z, Kryštof V, Šipl M: Zinc (II) complexes with potent cyclindependent kinase inhibitors derived from 6-benzylaminopurine: synthesis, characterization, X-ray structures and biological activity. J Inorg Biochem 2006, 100:214-225.

16. Szűčová L, Trávníček Z, Zatloukal M, Popa I: Novel platinum (II) and palladium (II) complexes with cyclin-dependent kinase inhibitors: Synthesis, characterization and antitumour activity. Bioorg Med Chem 2006, 14:479-491.

17. Trávníček Z, Marek J: X-ray structural characterizations of the reaction products between $\mathrm{ZnCl}_{2}$ and 6-benzylaminopurine derivatives in different acidic conditions. J Mol Struct 2009, 933:148-155.Z.

18. Novotná R, Trávníček Z, Popa I: Synthesis and characterization of the first zinc (II) complexes involving kinetin and its derivatives: $\mathrm{X}$-ray structures of 2-chloro-N6-furfuryl-9-isopropyladenine and [ $\mathrm{Zn}$ (kinetin) $\left.{ }_{2} \mathrm{Cl}_{2}\right] \cdot \mathrm{CH}_{3} \mathrm{OH}$. Inorg Chim Acta 2010, 363:2071-2079.

19. Muthiah PT, Mazumdar SK, Chaudhuri S: Metal ions-nucleobases interactions: preparation and crystal structures of trichloroadeninium zinc (ii)(form ii) and a similar zinc complex of arprinocid [6-amino-9-(2-chloro-6-fluorobenzyl) purine]. J Inorg Biochem 1983, 19:237-246.

20. Šponer JE, Leszczynski J, Glahé F, Lippert B, Šponer J: Protonation of platinated adenine nucleobases. Gas phase vs condensed phase picture. Inorg Chem 2001, 40:3269-3278.

21. Umadevi B, Muthiah PT, Stanley N, Varghese B: Synthesis, characterization and crystal structure of dichlorobis(N6-furfuryladeninium) copper(II) chloride. Indian J Chem Sect A Inorg Bio-inorg Phys Theor Anal Chem 2002, 41:737-740

22. Balasubramanian TP, Muthiah PT, Ananthasaravanan, Mazumdar SK: Metalnucleobase interactions: synthesis and crystal structure of trichlorobis (N6-benzyl adeninium) copper(II) chloride dehydrate. J Inorg Biochem 1996, 63:175.

23. Stanley N, Muthiah PT, Luger P, Weber M, Geib SJ: Metal-nucleobase interactions: Interplay of coordination and hydrogen bonding in cadmium (II) complexes of N6-substituted adenines. Inorg Chem Commun 2005, 8:1056-1059.

24. Trávníček Z, Matiková-Malarová M: 6-(3-Bromobenzylamino)purin-3-ium chloride. Acta Cryst E 2006, 62:05097-05099.

25. Bruker: APEX2, SAINT and SADABS. Madison, Wisconsin, USA: Bruker AXS Inc; 2008.

26. Sheldrick GM: A short history of SHELX. Acta Cryst A 2008, 64:112-122.

27. Spek AL: Structure validation in chemical crystallography. Acta Cryst D 2009, 65:148-155.

28. Macrae CF, Bruno IJ, Chisholm JA, Edgington PR, McCabe P, Pidcock E, Rodriguez-Monge L, Taylor R, van de Streek J, Wood PA: Mercury CSD 2.0 - new features for the visualization and investigation of crystal structures. J Appl Crystallogr 2008, 41:466-470.

29. Umadevi B, Stanley N, Muthiah PT, Bocelli G, Cantoni A: N6-Benzyladenine hydrobromide and the solid-state conformation of cytokinins. Acta $E$ 2001, 57:0881-0883.

30. Xia M, Ma KR, Zhu Y: Synthesis and crystal structure of hydrate adduct of 6-benzylaminopurine and 5-sulfosalicylic acid $\left[\left(\mathrm{C}_{12} \mathrm{H}_{12} \mathrm{~N}_{5}\right)\left(\mathrm{C}_{7} \mathrm{H}_{5} \mathrm{O}_{6} \mathrm{~S}\right)\right.$. $\mathrm{H}_{2} \mathrm{O}$ ]. J Chem Crystallogr 2010, 40:634-638.

31. Korszun ZR, Knight C, Chen CM: A stereochemical model for cytokinin activity. FEBS Lett 1989, 243:53-56. 
32. Rao P, Ghosh S, Maitra U: Binding of 9-N-butyladenine by carboxylic acids: Evidence that Hoogsteen binding can dominate in solution. J Phys Chem B 1999, 103:4528-4533.

33. Dobrzynska D, Jerzykiewicz LB: Adenine ribbon with Watson-crick and hoogsteen motifs as the "double-sided adhesive tape" in the supramolecular structure of adenine and metal carboxylate. J Am Chem Soc 2004, 126:11118-11119.

34. Dauter Z, Jaskolski M: How to read (and understand) volume A of international tables for crystallography: an introduction for nonspecialists. J Appl Cryst 2010, 43:1150-1171.

35. Wilkinson HS, Harrison WT: Propane-1, 3-diaminium bis (dihydrogenarsenate). Acta E 2005, 61:m1289-m1291.

36. Cuny J, Gougeon P, Gall P: Redetermination of $\mathrm{Zn}_{2} \mathrm{Mo}_{3} \mathrm{O}_{8}$. Acta E 2009, 65:i51-i51.

Cite this article as: Jennifer et al:: Importance of halide involving

interactions at Hoogsteen sites in supramolecular architectures of some coordination metal complexes of $\mathrm{N}^{6}$-benzyl/furfuryl adenine. Chemistry

Central Journal 2014 8:58.

\section{Publish with ChemistryCentral and every scientist can read your work free of charge \\ "Open access provides opportunities to our colleagues in other parts of the globe, by allowing anyone to view the content free of charge." \\ W. Jeffery Hurst, The Hershey Company. \\ - available free of charge to the entire scientific community \\ - peer reviewed and published immediately upon acceptance \\ - cited in PubMed and archived on PubMed Central \\ - yours - you keep the copyright \\ Submit your manuscript here: \\ http://www.chemistrycentral.com/manuscript/<smiles>c1ccccc1</smiles> 